Review Article

\title{
Let Food be thy Medicine and Medicine be thy Food
}

\author{
Mohammad Altaf', $\underline{\text { Sajitha K }}{ }^{2}$, Rakshith K $^{3}$, Rudresh S $^{4}$ \\ ${ }^{1,3}$ Assistant Professor, ${ }^{2}$ Professor and HOD, ${ }^{4}$ Associate Professor, Department of Swsthavritta and Yoga, Sri Sri College of \\ Ayurvedic Science and Research, Bengaluru, Karnataka, India.
}

DOI: https://doi.org/10.24321/2394.6547.201905

I $\quad \begin{array}{lllll}\mathbf{N} & \mathbf{F} & \mathbf{O}\end{array}$

Corresponding Author:

Mohammad Altaf, Department of Swsthavritta and Yoga, Sri Sri College of Ayurvedic Science and Research, Bengaluru, Karnataka, India.

E-mail Id:

md.aaltaf@gmail.com

Orcid Id:

https://orcid.org/0000-0001-6668-225X

How to cite this article:

Altaf M, Sajitha K, Rakshith K et al. Let Food be thy Medicine and Medicine be thy Food. J Adv Res Ayur Yoga Unani Sidd Homeo 2019; 6(1\&2): 28-29.

Date of Submission: 2019-09-27

Date of Acceptance: 2019-10-22
$\begin{array}{llllllll}\mathbf{A} & \mathbf{B} & \mathbf{S} & \mathbf{T} & \mathbf{R} & \mathbf{A} & \mathbf{C} & \mathbf{T}\end{array}$

Ahara is the basic constituent of body, without food body perishes. Various constituents of food nourish various basic elements of the body. Food is the fine blend of various nutrients and hence acts as medicine for the body, diet for prevention disorders like obesity, diabetes, cancer, stroke and kidney stones etc. Promote longevity, health and happiness, natural immunity and food relation. The food should be wholesome, palatable and congenial not merely to gratify the sense. To neglect this body leads to death and destruction of the self. Let the food be your medicine and medicine be your food.

Keywords: Ayurveda, Mind, Body, Food, Mahabhaishajya

\section{Introduction}

This physical body is the outcome of the type of diet one eats and so also the diseases. It is told that food is the primary requisite without which man cannot develop his anatomical body to the gross form as it exists. ${ }^{1}$ It is stated that the Sun radiates heat which evaporates the water from sea and converts into water vapours and then into clouds from which rain fall to earth. Human beings do farm on earth and cultivate the crops which produces food which when consumed creates the energy that maintains the body energy and that energy is responsible for the physical and chemical activities in the body.

The nutritional contents of what we eat determine the composition of our cell membranes, bone marrow, blood, hormones, tissue, organs, skin and hair. Our bodies are replacing billion of cells every day and using the food we consume as the source to replenish the loss. ${ }^{2}$ This energy comes from the food we eat; our bodies digest the food by breaking it down into simpler substances and also release the energy. The food should be wholesome, palatable and congenial to the body and should not be eaten merely to gratify the sense. It should promote longevity, health and happiness. Food in the form of nourishment is finally assimilated in various forms throughout the body. Water is needed to help digestion and assimilation.

The food is fine blend of various useful components such as Carbohydrates, proteins, fats, vitamins and mineral for the growth, development and wear and tear of tissues, also to improve immunity and treat the disease condition naturally. ${ }^{3}$ Many a times proper diet itself pacifies the disease, medicine may not be needed there. ${ }^{4}$

Your brain requires a constant supply of fuel as it works untiredly $24 / 7$, even while you are sleeping. The fuel comes from the food you eat and what in that fuel makes all the 
difference. ${ }^{5}$ Putting it simply, what you eat directly affects the structure and function of your brain and ultimately your mood. Like an expensive car, your brain functions best when it gets only premium fuel. Eating high quality foods that contains lots of vitamins, minerals and anti-oxidants nourishes the brain and protest it from oxidative stress the waste (free radicals) produced when the body uses oxygen, which can damage cells.

Unfortunately, just like an expensive car, your brain can be damaged if you ingest anything other than premium fuel. If substances from low-premium fuel such as what you get from processed or refined foods gets to the brain. For example, diets high in refined sugars, are harmful for the brains. In addition to worsening your body regulation of insulin, they also promote inflammation and oxidative stress.

Eating well helps to reduce the risk of physical health problems like heart diseases and Diabetes and cancer and promotes overall health of an individual. Eating a diet rich in vegetables and fruits reduces the risk of heart diseases including heart attack and stroke, protect against certain types of cancers. Diet rich in fibre reduces the risk of obesity and type 2 diabetes. Fruits rich in potassium lower the blood pressure and reduce the risk of developing kidney stones and help to keep the bones strong. The consumption of vegetables helps in reducing the calorie intake as these are low calorie food items.

The body is residence of the individual self. If it were to perish from lack of food the self would leave it just like a paying guest who refuses to reside any longer in a decaying house. The body therefore has to be protected to house the self. To neglect this body leads to death and destruction of the self. ${ }^{6}$ Shvetaketu lived on fluid for fifteen days and lost his power of thinking but regained it as soon as he ate solid food again, his power of speech diminished when he went without fats. This experience revealed to him that the mind is the product of food, energy of fluids and speech of fats.

\section{Conclusion}

So, the food is also called as Maha-bhaishajya meaning wonderful medicine which can prevent, protect and cure the body when consumed properly. Let the food be your medicine and medicine be your food.

\section{Conflict of Interest: None}

\section{References}

1. Rao MV. A text of Swasthavrtta. $1^{\text {st }}$ ed. Chaukhambha Orientalia, Varanasi. 2014; 78.

2. Vidya R. Handbook of preventive and social Medicine. $9^{\text {th }}$ ed. Jaypee Brothers Medical Publishers, New Delhi. 2002; 41. Available from: http://www.jaypeebrothers. com/pgDetails.aspx?book_id=9788171793808.
3. Bargale SS, Shashirekha HK. Text book of Swasthavritta. $1^{\text {st }}$ ed. Chaukhambha Sanskrit Pratishthan, Varanasi. 2016; 108. Available from: https://www.exoticindiaart. com/book/details/text-book-of-swasthavrittaaccording-to-new-syllabus-ccim-new-delhi-NAM798/.

4. Frawley D. Ayurveda and the Mind the Healing of Consciousness. $1^{\text {st }}$ ed. Motilal Banarsidas, Varanasi, 2011; 3.

5. Park K. Park's text book of preventive and social Medicine. $18^{\text {th }}$ ed. Banarsidas Bhanot, Jabalpur. 2005; 441. Available from: http://www.communityhealth. in/ commun26/wiki/index.php?title=Park\%27s_ Textbook_of_Preventive_and_Social_Medicine.

6. Gupta LP. Biogenic secrets of food in ayurveda. $1^{\text {st }} \mathrm{ed}$. Chaukhambha Sanskrit Pratishthan, Delhi. 2011; 2. Available from: http://terment.ru/en/?q=Biogenic $+S$ ecrets+of+Food+in+Ayurvedic+-+L.P.+Gupta. 